\title{
Limnological research in the Iberian Peninsula: a ten-year survey of published literature
}

\author{
Biel Obrador* and Núria Bonada
}

Departament d'Ecologia, Facultat de Biologia, Universitat de Barcelona (UB), Diagonal 643, 08028 Barcelona, Catalonia, Spain.

* Corresponding author: obrador@ub.edu (+34 93403 1375)

Received: 03/02/2014

Accepted: 01/04/2014

\begin{abstract}
Limnological research in the Iberian Peninsula: a ten-year survey of published literature

Research on limnology in southern Europe had achieved a notable presence in the international arena before the onset of the current dramatic cuts in public investment in science. We assessed the limnological research published in peer-reviewed journals by Spanish and Portuguese (i.e., Iberian) researchers during the decade prior to the economic recession (2000 to 2009). The Thompson Reuters Web of Knowledge database was used to retrieve all publications on limnology authored by researchers affiliated with Spanish or Portuguese institutions independently of the geographical setting of the study. The publishing pattern was characterised in terms of authors, journals, and citation statistics. In addition, a thematic characterisation of the research was performed by a manual assignation of several categorical descriptors combined with a blind word count analysis. Iberian researchers produced an annual mean of 278 papers on limnology. Papers were published in journals that had impact factors ranging from 0.1 to 31.4, with a mean of 2.0. Based on citations, the impact of the Iberian limnological research was not due to a few highly cited papers but rather to a wide number of publications; each paper received a mean of 8 citations. The Iberian limnological research involved up to 5460 researchers, with a mean of 4.3 authors per paper. The research largely focused on fluvial systems, with $47 \%$ of total publications (2778) devoted to these ecosystems. There was a dominant focus on local, within-system aspects of study sites and the research was mostly restricted to the Iberian Peninsula; larger spatial scales of analysis (i.e., landscape, regional, or global) tended to be overlooked. Iberian research addressed fundamental (75\%) rather than applied (17\%) or methodological (5\%) questions and was vastly dominated by observational approaches $(75 \%)$. Interestingly, Iberian limnological research increased its scientific productivity during the analysed decade at a higher rate than its international counterpart (increase of $119 \%$ ). Overall, Iberian research on limnology appeared to be in good health during the analysed decade. Certain areas have been more studied than others, which opens opportunities to develop new research.
\end{abstract}

Key words: Limnology, Iberian Peninsula, bibliometric analysis, indexed publications.

\section{RESUMEN}

\section{La investigación en limnología en la Península Ibérica: análisis bibliométrico de una década}

Antes de los recortes en investigación por parte de las administraciones públicas, la investigación en limnología en el sur de Europa había adquirido una presencia notable a nivel internacional. En este trabajo, analizamos la producción limnológica publicada por investigadores españoles y portugueses (i.e., ibéricos) en revistas de revisión por pares, durante la década anterior a la recesión económica (2000 a 2009). La base de datos "Thompson Reuters Web of Knowledge" fue utilizada para descargar todas las publicaciones en limnología que tenían autores afiliados a instituciones españolas o portuguesas. Se analizó el patrón de publicación según autores, revistas y citas. Además, se realizó una caracterización temática de la investigación mediante la asignación manual de varias categorías y un análisis de conteo de palabras. Los investigadores ibéricos publicaron una media de 278 artículos en limnología por año. Estos artículos se publicaron en revistas con índices de impacto entre 0.1 y 31.4, con una media de 2.0. Respecto a las citas, el impacto de la investigación limnológica ibérica no se basó en pocos artículos muy citados sino en un amplio número de publicaciones, con una media de 8 citas por artículo. Un total de 5460 autores estuvieron implicados en la investigación limnológica realizada por, o en colaboración con investigadores ibéricos, con una media de 4.3 autores por artículo. La investigación ibérica en limnología fue de 
carácter mayoritariamente fluvial, representando un $47 \%$ del total de publicaciones (2778). También es destacable el enfoque local dentro de la Península Ibérica, ignorando, en gran parte, escalas espaciales mayores (paisaje, regional o global). La investigación ibérica se centró mayoritariamente en cuestiones fundamentales (75\%), en lugar de aplicadas (17\%) o metodológicas (5\%), y estuvo dominada por aproximaciones observacionales (75\%). Es interesante señalar que hubo un aumento de la productividad científica lo largo de la década analizada (119\%), a niveles incluso mayores que la registrada a nivel internacional. En general, la investigación ibérica en limnología presentó un buen estado de salud, con un nivel de internacionalización significativo. Algunas áreas han sido mucho más estudiadas que otras, lo que abre oportunidades para desarrollar nuevas líneas de investigación.

Palabras clave: Limnología, Penísula Ibérica, estudios bibliométricos, publicaciones científicas.

\section{INTRODUCTION}

Bad times for science in southern European countries. Uncertainty and regression due to public budget cuts have dramatically affected the present situation at a time when these countries were approaching maturity (Nature Editorial, 2009; Moro-Martín, 2012). During the decades preceding the current economic situation, scientific research had increased notably in these countries, reaching levels comparable to other developed nations (Sanz \& Cruz, 2010; Chinchilla-Rodríguez et al., 2010). In the case of limnological research in particular, scientists in Spain and Portugal had developed a modern and active network of researchers with a presence in the international scientific arena. Most of this advancement in limnology had been undertaken by members of the Iberian Association of Limnology (AIL: Asociación Ibérica de Limnología, formerly AEL: Asociación Española de Limnología). Initially auspiced and influenced by the eminent professor Ramon Margalef (19192004 ), the society celebrated its $30^{\text {th }}$ anniversary in 2010 and currently supports the efforts of more than 400 researchers, professionals, and managers focused on inland waters.

Given the current critical situation for scientific studies, several questions arise regarding the outcomes of limnological research performed by Iberian researchers, especially in terms of its quantity and quality in the international context. Analysis of the published literature provides a dynamic and objective overview of the research in a given discipline and constitutes a fundamental tool that is increasingly used to characterise scientific research for evaluation purposes and to define priority research areas (Luukkonnen, 1990, Russell \& Rousseau, 2002; and see Mane \& Börner, 2004, and Northcote \& Lobón-Cerviá, 2008, for examples).

Here we address the status of the limnological research conducted by Iberian researchers through a bibliometric analysis of published literature in the decade prior to the economic recession (i.e., 2000-2009). We analysed purely bibliometric descriptors (i.e., authors, journals, and citation statistics), as well as thematic descriptors (i.e., major topics of limnological research, subdisciplines within limnology, and focus), and investigated the existence of temporal trends within the considered time span. In our survey, we did not analyse the limnology of aquatic systems in the Iberian Peninsula but limnological research carried out by Iberian researchers, thus including research performed in other regions. Therefore, the term 'Iberian limnology' refers here to research on limnology performed by Iberian researchers. Our goal was to provide the scientific community with a snapshot of the activity in this discipline by means of an objective analysis of its most fundamental outcome. Our results could also help to guide future research toward less studied topics or areas that could significantly contribute to the recovery of research in these southern European countries. 


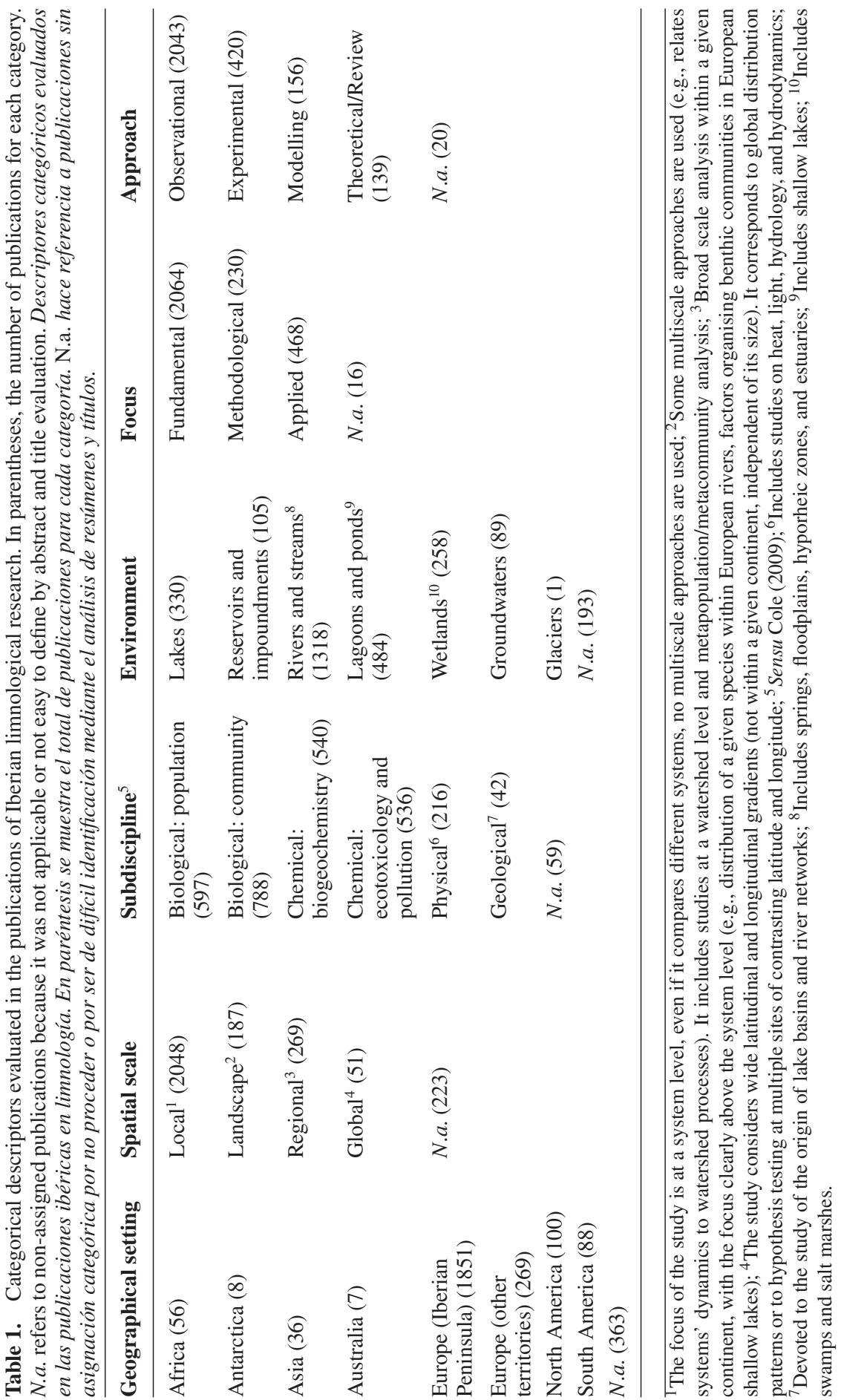




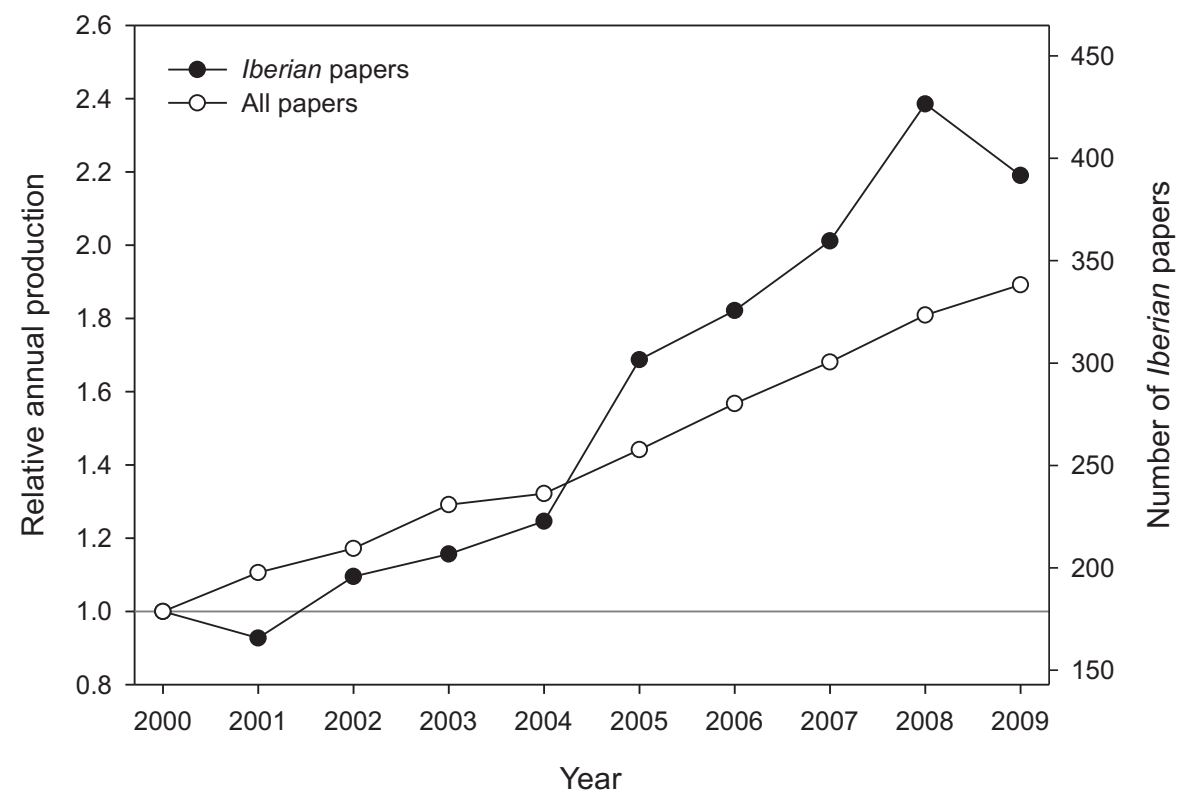

Figure 1. Temporal trends in the scientific production of limnological research. The relative annual production (i.e., number of papers published in a given year relative to the papers from the year 2000) is shown for Iberian papers (i.e., produced by Iberian authors, in filled circles) and for the total number of limnological papers in the WoK database (i.e., Iberian and non-Iberian authors, in open circles). As a reference, the absolute number of Iberian papers is shown on the right-hand axis. Evolución temporal de la producción científica en limnología. Se muestra la producción anual relativa (número de artículos publicados cada año en relación a los publicados en el año 2000) para los autores ibéricos (círculos negros) y para el total de artículos sobre limnología en WoK (círculos blancos). El eje de la derecha muestra el número absoluto de artículos de autores ibéricos.

\section{METHODS}

Data were obtained from the Thompson Reuters ISI Web of Knowledge (WoK) database in January 2010. The search criteria were designed to retrieve all scientific literature on limnology published by authors from Spain or Portugal (hereafter, Iberian) in the category Science and Technology.

The search was based on the existence of certain terms referring to continental water bodies in the title, abstract, or keywords fields of the WoK database. The list of terms was obtained from Cole (2009) and consisted of: Endorheic, Floodplain, Fluvial, Groundwater, Hyporheic, Impoundment, Inland water, Lagoon, Lake, Lentic, Lotic, Marsh, Pond, Reservoir, Riparian, River, Springs, Stream, Swamp, Water body, and Wetland. Singular, plural, and other forms of these terms with the same root (e.g., Hyporheos) were included in the search. The search included filters by time span (i.e., from 2000 to 2009) and authors' affiliations (i.e., limited to institutions in Spain or Portugal). The restriction of the affiliation was not limited to the first or leading author, any paper co-authored by an Iberian author was included. At the time of WoK database retrieval, it was not possible to download the authors' affiliations for each record and thus no analysis of the weight of Iberian authors or institutions could be undertaken. For comparison with international research on limnology, we performed a second data retrieval using the same search criteria but without any restriction on authors' affiliations.

The retrieved database for Iberian limnology was locally stored and included the fields $A u$ thors, Year of publication, Title, Affiliation, $A b$ stract, Journal, Volume, Pages, and Times cited. The database was further filtered to include only those papers published in journals indexed in the Journal Citation Report $囚$ (JCR) of the WoK and belonging to any of the following subject categories: Biodiversity and Conservation, Biology, 
Ecology, Environmental Sciences, Evolutionary Biology, Limnology, Marine and Freshwater Biology, Multidisciplinary Sciences, or Water Resources. The final database consisted of a total of 5307 records.

The search criteria were selected after an assessment of their efficiency at retrieving limnological papers from the WoK database. This assessment was carried out by comparing the performance of various combinations of criteria in retrieving the publications by the five most prolific authors in the database. The criteria that minimised Type II errors were selected, thereby minimising false negatives during database retrieval. This resulted in a considerable presence of Type I errors in our database (i.e., false positives, papers that included one of the selected terms but were not related to limnology). A manual filter was then performed to select only those papers that focused on limnology by reading the abstract and evaluating the papers itself if necessary. The non-selected records were primarily from papers dealing with non-limnological aspects of continental aquatic environments (e.g., astronomical, sanitary, industrial, or social aspects of inland waters) or with purely marine or terrestrial ecosystems. The final number of pa- pers included, after the filtering, was 2778, more than half of the initial retrieved database $(52.34 \%)$. This high level of non-relevant papers made a detailed comparison with international limnology unfeasible. Thus, for example, the same search in WoK with no filter for the authors' affiliations resulted in 560748 records.

The filtering process for the database was accompanied by a manual assignation of a set of unique categorical descriptors to each paper (Table 1). The type of aquatic ecosystem studied (i.e., the Environment field) identified 7 different types of ecosystems. The geographical range of the research assessed the geographical areas where the study sites were located in each paper (i.e., the Continent field, including 8 categories). The Focus field determined whether the study addressed fundamental, applied, or methodological questions (i.e., 3 categories). The Approach field dealt with the methodology used to test the hypotheses, and included 4 categories: observational (i.e., based on assessment of empirical, primarily field, data), experimental (i.e., in the laboratory or the field), modelling (i.e., based on mathematical models, dynamic or not), or theoretical (which included reviews). The spatial scale of the study (i.e., the Scale field, with 4 cat-

Table 2. Bibliometric descriptors of Iberian limnological research in the decade 2000-2009 (mean \pm SD). Descriptores bibliométricos de la investigación ibérica en limnología durante el periodo 2000-2009 (media \pm SD).

\begin{tabular}{ll}
\hline Descriptors & Value \\
\hline Total number of papers & 2778 \\
Number of papers per year & $278 \pm 95$ \\
Total number of authors involved & 5460 \\
Number of authors per paper & $4.3 \pm 2.7$ \\
Range of number of autors per paper & $1-49$ \\
Individual productivity (number of papers per author) & $2.2 \pm 3.3$ \\
Range of individual productivity & $1-57$ \\
Percentiles of individual productivity (number of papers for the $25 \%, 50 \%$ and $75 \%$ of authors) & $1 / 1 / 2$ \\
Total number of journals & 292 \\
Percentiles (number of journals covering $25 \%, 50 \%$ and $75 \%$ of papers) & $7 / 28 / 68$ \\
Impact factor (weighted) & $2.0 \pm 1.4$ \\
Range of impact factor (weighted) & $0.1-31.4$ \\
Number of citations per paper & $8 \pm 13$ \\
Range of number of citations per paper & $0-173$ \\
Percentiles of citation (number of papers covering $25 \%, 50 \%$ and $75 \%$ of total cites) & $84 / 275 / 649$ \\
\hline
\end{tabular}


egories) addressed whether the questions or hypotheses were defined at a local, landscape, regional, or global level. Finally, the Subdiscipline field identified 6 different subdisciplines within limnology, as defined by Cole (2009): population and community ecology, which are primarily biological subdisciplines; biogeochemistry (in a wide sense, including ecosystem ecology), ecotoxicology and pollution, which is primarily a chemical subdiscipline; and physical and geological subdisciplines (see Table 1 for details).

Data were analysed in terms of standard bibliometric descriptors (i.e., total publications, individual productivity, and basic statistics on journals, authors, and citations) and by evaluating the distribution of publications within the different categories of considered categorical descriptors (Table 1). In all cases, Mann-Kendall tests were used to assess the existence of significant trends in the considered variables. The Mann-Kendall trend test is a non-parametric test based on the Kendall Rank correlation test that has been widely used in time series analysis. A significant and positive Tau indicates a positive trend whereas a non-significant Tau indicates that there is no temporal trend. A Bonferroni correction was applied to the obtained $p$-values.

Finally, to objectively identify hot topics in Iberian limnological research, a blind word count was performed on all titles and abstracts in the database on the assumption that the terms with the highest frequency corresponded to hot topics. The word counts were performed with the lexical

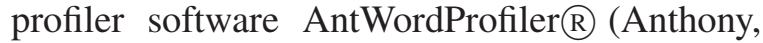
2013) and excluded articles, prepositions, verbs, adjectives, and adverbs.

\section{RESULTS AND DISCUSSION}

\section{Bibliometric descriptors of Iberian limnology}

\section{Scientific production}

The annual production of Iberian limnological research from 2000-2009 was 278 95 papers per year (mean $\pm \mathrm{SD}$ ), with a marked increasing trend during the analysed decade (mean increase of 30 publications per year; Man-Kendall tau $=0.911 ; p<0.001$; Fig. 1). An increase in the

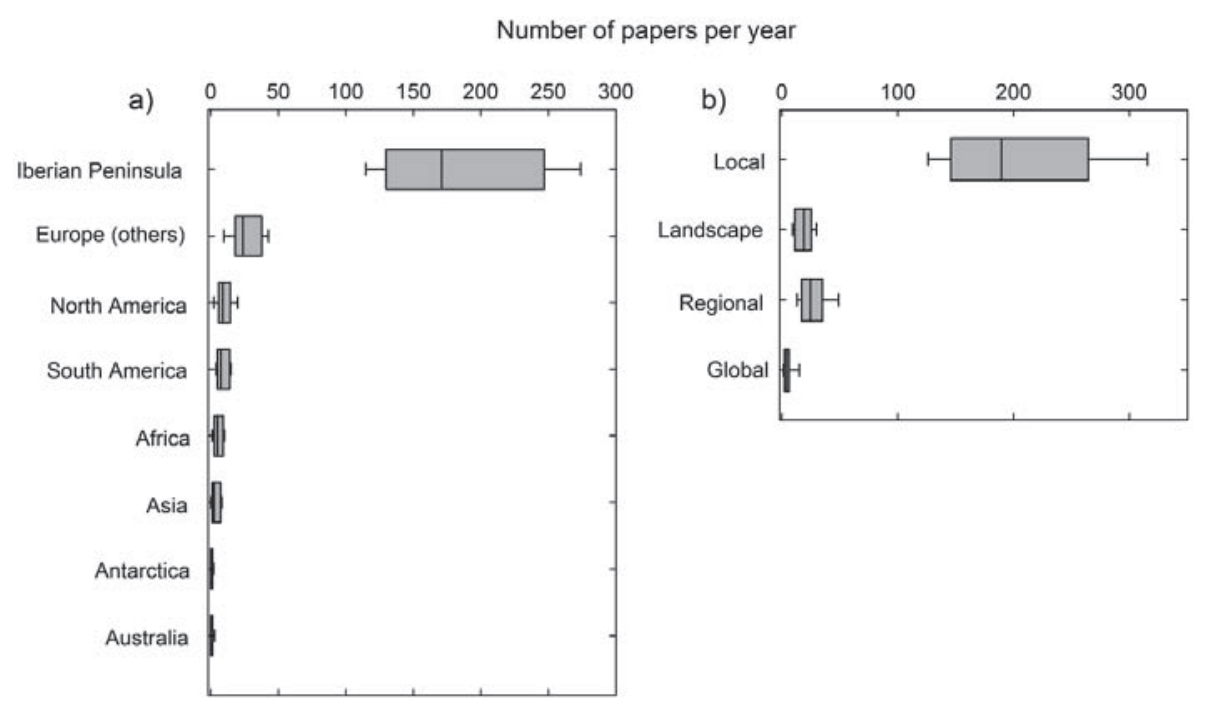

Figure 2. Spatial setting of the Iberian limnological research. a) Geograhical location of the study sites; b) Spatial scale of the approach. The graphs show the median (line), the 25th and 75th percentiles (box), and the 5th and 95th percentiles (whiskers). See Table 1 for details on the definition of the categories. Características espaciales y geográficas de la investigación ibérica en limnología. a) Localización geográfica de las áreas de estudio; b) Escala espacial de la investigación. Los gráficos muestran la mediana (línea), los percentiles $25 \%$ y $75 \%$ (caja) y los percentiles $5 \%$ y $95 \%$. Ver Tabla 1 para más información sobre el significado de las categorías. 
publications on limnology in general (i.e., not restricted to Iberian authors) was also observed during this period, but at a slower rate (Student's $t=3.98 ; p<0.05)$. Thus, whereas the Iberian annual production doubled in one decade (i.e., an increase of $119 \%$ ), the increase in total publications on limnology in the WoK database was $89 \%$.

\section{Authorship}

The Iberian limnological research involved a total of 5460 authors, with a mean of $4.3 \pm 2.7$ authors per paper (Table 2) and a maximum of 49. The number of authors per paper was lower than the mean number of authors within the Spanish scientific system when all scientific disciplines were considered $(6.2 \pm 0.4$ in all disciplines; Moya-Anegón \& Chinchilla-Rodríguez, 2007; Chinchilla-Rodríguez et al., 2010). The total individual productivity during the analysed decade was $2.2 \pm 3.3$ papers per author. The distribution of the number of papers per author was highly skewed (skewness $=6.13 \pm 0.03$ ), depicting a publishing system based on few prolific authors and many authors with few publications. Thus, up to $75 \%$ of authors published only 2 papers during the studied period, $10 \%$ published only 4 papers, and only $3 \%$ published 10 papers in one decade (i.e., equivalent to one paper per year) (Table 2). On the other extreme, in terms of productivity, the top ten authors published an average of 39 papers each during the analysed decade. It must be noted that the individual productivity shown here does not include all the publications of each author but only those devoted to limnology, therefore comparisons with reference values are not applicable. Additionally, because we could not identify individual affiliations for each author, the analysis of individual productivity shown here must be considered not as the productivity of Iberian authors but of all authors involved in Iberian limnology.

\section{Journal and citation statistics}

Iberian limnological research was published in a diverse group of journals (i.e., a total of 292 indexed journals). Of these, 68 journals housed
$75 \%$ of all the publications. The number of journals publishing Iberian limnological research markedly increased throughout the decade (a linear increase starting at 83 journals in the year 2000; Man-Kendall tau $=0.87, p$-value $=0.001$ ). The top ten journals for Iberian limnologists published $31 \%$ of total publications during the decade. These publications were Hydrobiologia (215 papers), Estuarine Coastal and Shelf Science (115 papers), Freshwater Biology (111 papers), Science of the Total Environment (73 papers), Journal of Fish Biology (66 papers), Archiv für Hydrobiologie (65 papers), Chemosphere (60 papers), Environmental Pollution (51 papers), International Review of Hydrobiology (50 papers) and Water Research (48 papers). The journal of the Iberian Association of Limnology, Limnetica, was indexed in the JCR of the WoK after the analysed decade. This journal, which has a current impact factor of 1.113 (Journal Citation Reports of 2012), is expected to be targeted by Iberian researchers in the near future.

Despite the fact that the mean impact factor of the journals, weighted by the number of publications in each journal, was low (mean $2.0 \pm 1.4$ ), the publishing journals covered a wide range of impact factors reaching a maximum of 31.4 and a minimum of 0.1 (Table 2). This low value, in comparison with the international standards for excellence in research, must, however, be placed in the context of the generally low impact of ecological and environmental sciences in general and limnology in particular (Cole, 2009). Thus, the impact factors of the JCR categories in which limnological research is mainly published are within this range or below it: Limnology (median impact factor of this category 1.196), Marine \& Freshwater Biology (median 1.352), Water Resources (median 1.103), Ecology (median 1.665), and Environmental Sciences (median 1.476). Iberian limnologists thus publish their research in specific journals of intermediate to high impacts within a scientific discipline that is characterised by generally low impact journals (Cole, 2009).

The citation statistics of Iberian limnology showed a mean of 8 citations per paper and a maximum of 173 (Table 2). As a reference point, 
the H-index of Iberian limnological research during 2000-2009 would be 49 (i.e., Iberian limnology produced 49 papers that were cited 49 times each). Because the number of citations reported here corresponds to the time of data collection from the WoK database (i.e., January 2010), our results underestimate the mid-term impact of Iberian limnology, especially in the last years of the considered period; the citing half lives of the scientific disciplines considered here range from 6.7 to $>10$ years (Thomson Reuters, 2009). The number of citations per paper is, as expected, highly variable (coefficient of variation of $160 \%$, Table 2). Interestingly, the frequency distribution of the citations follows a log-normal model $\left(\chi^{2}=3.35, p=0.34\right)$. This means that

Table 3. Results of the Mann-Kendall trend tests for temporal changes in each category. *: significant at $p<0.025$ (two-sided tau distribution), ${ }^{a}$ : significant after a Bonferroni correction. Resultados del análisis de tendencias temporales de Mann-Kendall para cada categoría. *: significativo con p < 0.025 (distribución de tau de dos colas), a : significativo después de aplicar una corrección de Bonferroni.

\begin{tabular}{|c|c|c|c|}
\hline Descriptor & Category & Tau & $p$-value \\
\hline \multirow{8}{*}{ Geographical setting } & Africa & 0.41 & 0.1238 \\
\hline & Antarctica & 0.47 & 0.0998 \\
\hline & Asia & 0.55 & 0.0373 \\
\hline & Australia & -0.14 & 0.6826 \\
\hline & Europe (Iberian Peninsula) & 0.78 & $0.0024 *$ \\
\hline & Europe (other territories) & 0.76 & $0.0030 *$ \\
\hline & North America & 0.58 & $0.0248^{*}$ \\
\hline & South America & 0.60 & $0.0236^{*}$ \\
\hline \multirow[t]{4}{*}{ Spatial scale } & Local & 0.87 & $0.0073 * a$ \\
\hline & Landscape & 0.76 & $0.0030^{*}$ \\
\hline & Regional & 0.69 & $0.0073 *$ \\
\hline & Global & 0.74 & $0.0050 *$ \\
\hline \multirow[t]{6}{*}{ Subdiscipline } & Biological: population & 0.63 & $0.0153 *$ \\
\hline & Biological: community & 0.69 & $0.0073 *$ \\
\hline & Chemical: biogeochemistry & 0.69 & $0.0073^{*}$ \\
\hline & Chemical: ecotoxicology and pollution & 0.78 & $0.0024 *$ \\
\hline & Physical & 0.82 & $0.0013^{*}$ \\
\hline & Geological & 0.12 & 0.7123 \\
\hline \multirow[t]{7}{*}{ Environment } & Lakes & 0.30 & 0.2740 \\
\hline & Reservoirs and impoundments & 0.57 & 0.0305 \\
\hline & Rivers and streams & 0.91 & $0.0003 * a$ \\
\hline & Lagoons and ponds & 0.66 & $0.0116^{*}$ \\
\hline & Wetlands & 0.63 & $0.0153 *$ \\
\hline & Groundwaters & 0.25 & 0.3672 \\
\hline & Glaciers & 0.15 & 0.7277 \\
\hline \multirow[t]{3}{*}{ Focus } & Fundamental & 0.87 & $0.0007 * a$ \\
\hline & Methodological & 0.90 & $0.0005^{* a}$ \\
\hline & Applied & 0.87 & $0.0007 * a$ \\
\hline \multirow[t]{4}{*}{ Approach } & Observational & 0.87 & $0.0007 * a$ \\
\hline & Experimental & 0.78 & $0.0024^{*}$ \\
\hline & Modelling & 0.75 & $0.0039 *$ \\
\hline & Theoretical / Review & 0.61 & $0.0191 *$ \\
\hline
\end{tabular}


the citation pattern in Iberian limnology is not based on just a few highly cited papers but rather on a wide corpus of publications which receive a variable number of citations each. Thus, up to 275 papers are needed to account for $50 \%$ of the total citations (Table 2).

\section{Thematic descriptors of Iberian limnology}

\section{Geographical setting and scale of analysis}

Iberian limnological research took place at locations on all continents but was markedly centred on the Iberian Peninsula, which accounted for $70 \%$ of total publications (Fig. 2a). The other continents accounted, individually, for less than $10 \%$ of the publications, with non-Iberian Europe being the second-most studied territory. Such low levels of internationality must not be seen as a reflection of low international networking among the researchers, which is not evaluated here, but in terms of the location of study sites. In this sense, most of the research (74\% of publications) showed local scales of analysis, whereas larger scale studies (i.e., landscape, regional, or global scales) were much less frequent (Fig. 2b). The small amount of attention paid to large scales of analysis disagrees with classical limnological analysis (Kalff, 1991), which, as with any ecological discipline, integrates patterns and processes at different spatial and temporal scales. Additionally, the omission of watershed processes is surprising given the expected strong effects of the catchment on the functioning of aquatic ecosystems in some areas of the Iberian Peninsula, such as the Mediterranean area (Álvarez-Cobelas et al., 2005). Therefore, in terms of the geographical setting, Iberian limnological research exhibits a marked identity defined by studies focused on local, within-system aspects, and is restricted to sites within the Iberian Peninsula.

The analysis of trends regarding the spatial setting of the research showed only weak indications of change throughout the analysed decade. The publications at a local scale, and those set in the Iberian Peninsula, showed the highest rates of change (tau $=0.87$ and 0.78 , respectively,
Table 3). The observed significant increase in the number of publications at landscape, regional, and global scales over time suggests an increasing interest of Iberian limnologists in larger scale processes; however, these categories were still poorly represented at the end of the decade (data not shown). The research located in European territories (i.e., either Iberian or non-Iberian) showed the maximum increase in the number of publications (Table 3). Minor increases were also observed in American sites. Research in North American and South American sites likely results from international networking with research groups in those regions; those regions may attract Iberian limnologists due to the presence of reference research centres and the ease of linguistic communication, respectively. All in all, these results suggest that site selection is mostly determined by geographical proximity, with most non-European territories highly underrepresented.

\section{Hot topics in Iberian limnology}

Published literature covered all the subdisciplines within limnology. There was a marked dominance of biological studies, (community and population studies accounted for up to $50 \%$ of publications), with chemical studies the next most common (biogeochemistry and ecotoxicology accounted for up to $39 \%$; Fig. 3a). Of minor importance were physical and geological papers, in agreement with the status of general limnology some decades ago (Lewis, 1995). All subdisciplines showed similar increases in the publishing rate except geological limnology, which showed no significant trend over time (Table 3 ).

The most fundamental characteristic of Iberian limnological research was its overwhelming focus on fluvial ecosystems. Studies on streams and rivers clearly dominated the publication corpus of Iberian researchers during the analysed decade, accounting for up to $47 \%$ of total publications (Fig. 3b). Moreover, the publication rate in fluvial environments notably increased over time $(\operatorname{tau}=0.91$, Table 3$)$. Such dominance of fluvial systems was not an artefact of the inclusion of estuarine systems in this category 


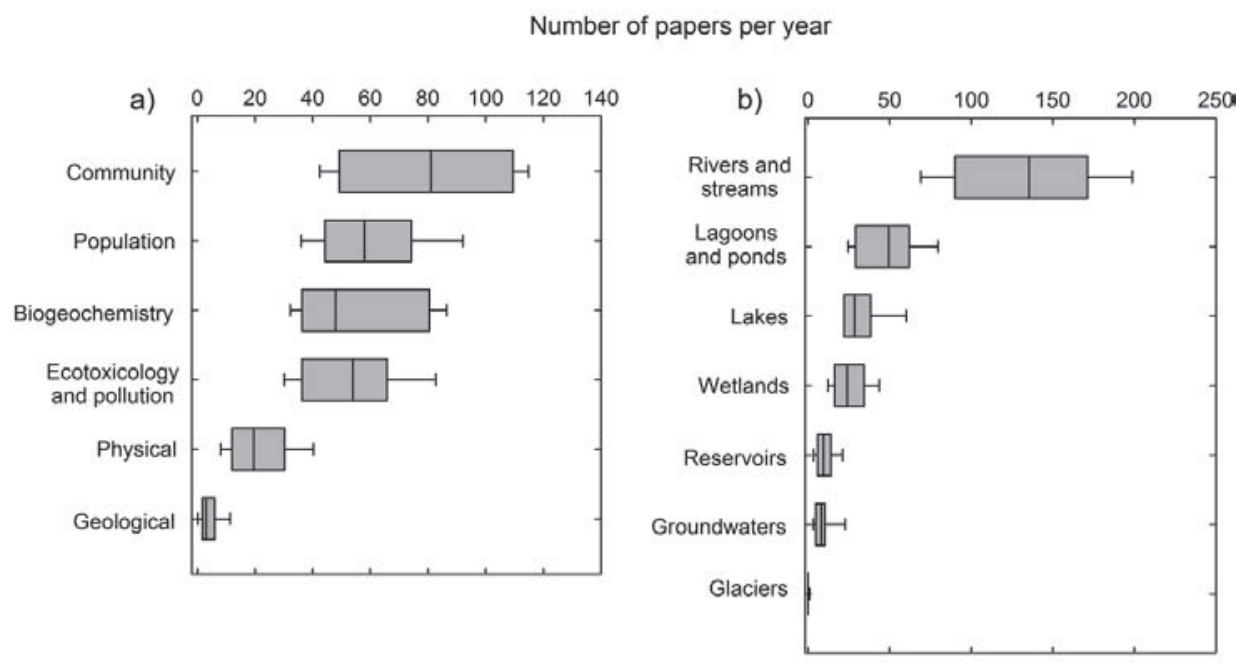

Figure 3. Thematic coverage of the Iberian limnological research. a) Subdiscipline within limnology and b) type of ecosystem studied. See Table 1 for details on the definition of the categories. Graphs as in Fig. 2. Temas de la investigación ibérica en limnología. a) Subdisciplina dentro de la limnología y b) tipo de ecosistema estudiado. Ver Tabla 1 para más información sobre el significado de las categorías. Gráficos como en la Fig. 2.

because estuarine papers accounted for a minor fraction of the papers assigned to this category (8\%). Unfortunately, we could not compare our results with the limnological research performed in an international context to assess whether this fluvial focus is a general property of limnology. We hypothesise that the low relevance of nonfluvial environments in limnological research is likely explained by the geomorphologic setting of the Iberian Peninsula. As seen before, Iberian limnology mostly focuses on the Iberian area, where lakes are scarce and the aquatic landscapes are dominated by flowing waters. It is noteworthy that publications on stagnant waters were dominated by lagoons and ponds, including shallow lakes (17\%, Fig. 3b), and that this category

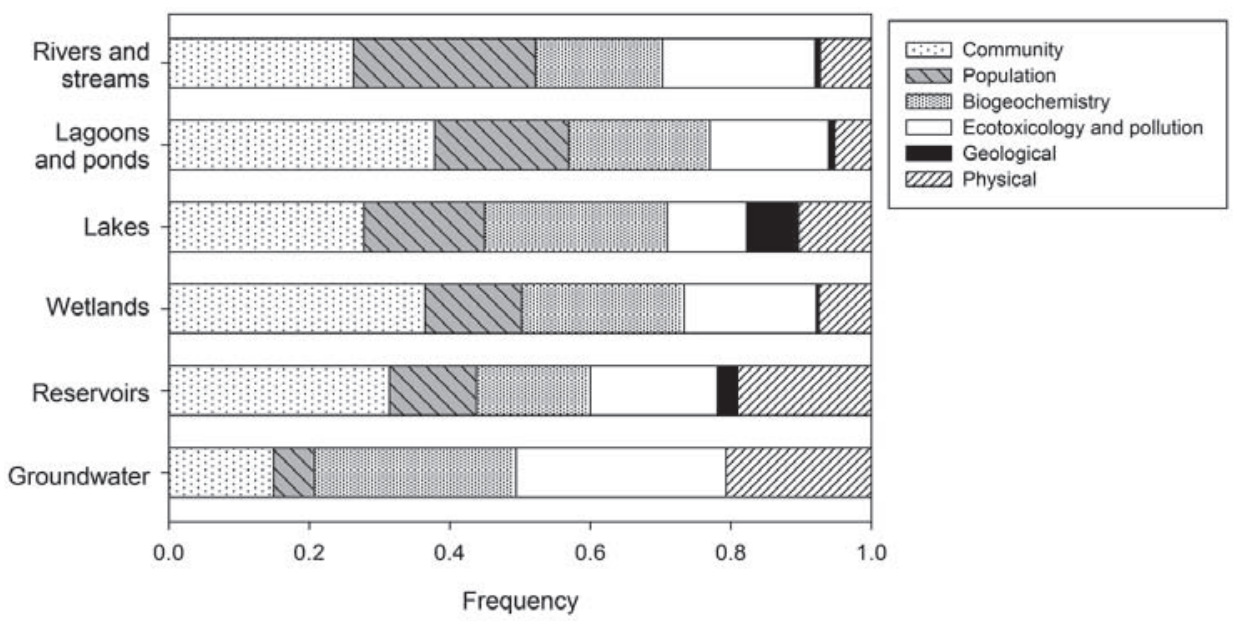

Figure 4. Relative distribution of the publications of the different limnological subdisciplines among the different types of ecosystems studied by the Iberian limnological researchers. Glaciers were excluded due to their low representation. Distribución relativa de las publicacions de diferentes subdisciplinas limnológicas entre los diferentes tipos de ecosistemes estudiados por investigadores ibéricos (los glaciares fueron excluidos debido a su baja representatividad). 
showed the second highest rate of increase after fluvial systems (tau $=0.66$; Table 3 ). Despite the notable presence of dams, weirs, impoundments, and reservoirs in the Iberian watersheds, reservoir limnology was of little importance in terms of publications (Fig. 3b) and exhibited no significant increase over time (Table 3). As stated by Álvarez-Cobelas et al. (2005), classical limnology based on cold deep lakes from temperate regions cannot be the dominant object of study in the Mediterranean region. However, the vast dominance of fluvial research over other types of ecosystems in the Iberian Peninsula is not in accordance with these authors, who suggest that, at least in the Mediterranean area, the high diversity of inland water ecosystems should imply high scientific effort to understand their specific ecologies.

Interestingly, the different subdisciplines within limnology received differential attention from researchers working on varying types of ecosystems (Fig. 4). Thus, the biological dominance was more marked in lagoons, ponds, rivers, and streams than in lakes, and had a minimal presence in the publications on groundwater, which mostly focused on chemical aspects. Population limnology was primarily addressed in studies on fluvial systems, where it had the same frequency as community limnology. Studies on lakes had the most even distribution of subdisciplines, most likely because geological limnology was only relevant in lakes. Physical limnology was studied primarily in reservoirs, groundwater, and lakes, with a minor presence in wetlands, lagoons, and ponds. This is likely because most of the studies on physical limnology dealt with water hydrodynamics and energy budgets, aspects of minor importance in the latter ecosystems.

Iberian limnology was clearly characterised by approaching fundamental questions of inland waters $(75 \%)$, with a small representation of publications devoted to applied $(17 \%)$ and methodological (8\%) concerns (Fig. 5a). The low relevance of applied limnology in Iberian research agrees with a classical view of limnology as a scientific discipline poorly connected to applications (Kalff, 1991) but does not reflect the current view of most scientific disciplines, including modern limnology. In addition, it does not agree with the high vulnerability of certain types of ecosystems in the Iberian Peninsula, which should require significant attention from the scientific community (Álvarez-Cobelas et al., 2005). Nonetheless, a potential bias that may have led to the under-representation of applied limnology in this study must be noted. A large portion of applied research relies on publications and media other than peer reviewed journals, technical papers, books, book chapters, and grey literature; these other media were not evaluated here. This could be the case, for example, with many publications on biomonitoring issues that were produced after the publication of the Water Framework Directive in 2000.

In terms of the scientific method and approach used, the research was markedly observational

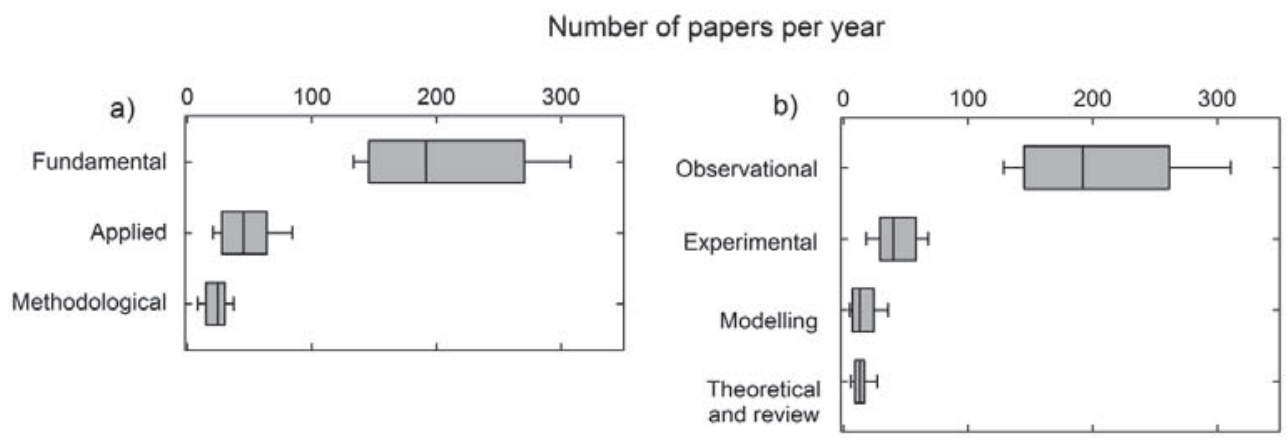

Figure 5. Design of the Iberian limnological research. a) Conceptual focus and b) methodological approach. See Table 1 for details on the definition of the categories. Graphs as in Fig. 2. Diseño de la investigación ibérica en limnología. a) Enfoque conceptual y b) aproximación metodológica. Ver Tabla 1 para más información sobre el significado de las categorías. Gráficos como en la Fig. 2. 
$(75 \%)$ and the researchers only secondarily used experimental $(15 \%)$ or modelling $(5 \%)$ approaches to test hypotheses (Fig. 5b).

The blind word analysis (Fig. 6) reflected a high frequency of appearance of a mix of lotic and lentic systems (terms river and stream were in the $3^{\text {rd }}$ and $9^{\text {th }}$ positions, respectively, whereas lake appeared in the $5^{\text {th }}$ position). This was confirmed by the overall absolute frequency of appearance of the terms used to retrieve the WoK database, based on Cole (2009): Water body (4015), River (2190), Lake (1981), Stream (1594), Lagoon (821), Wetland (669), Pond (653), Reservoir (589), Marsh (577), Springs (485), Ground-

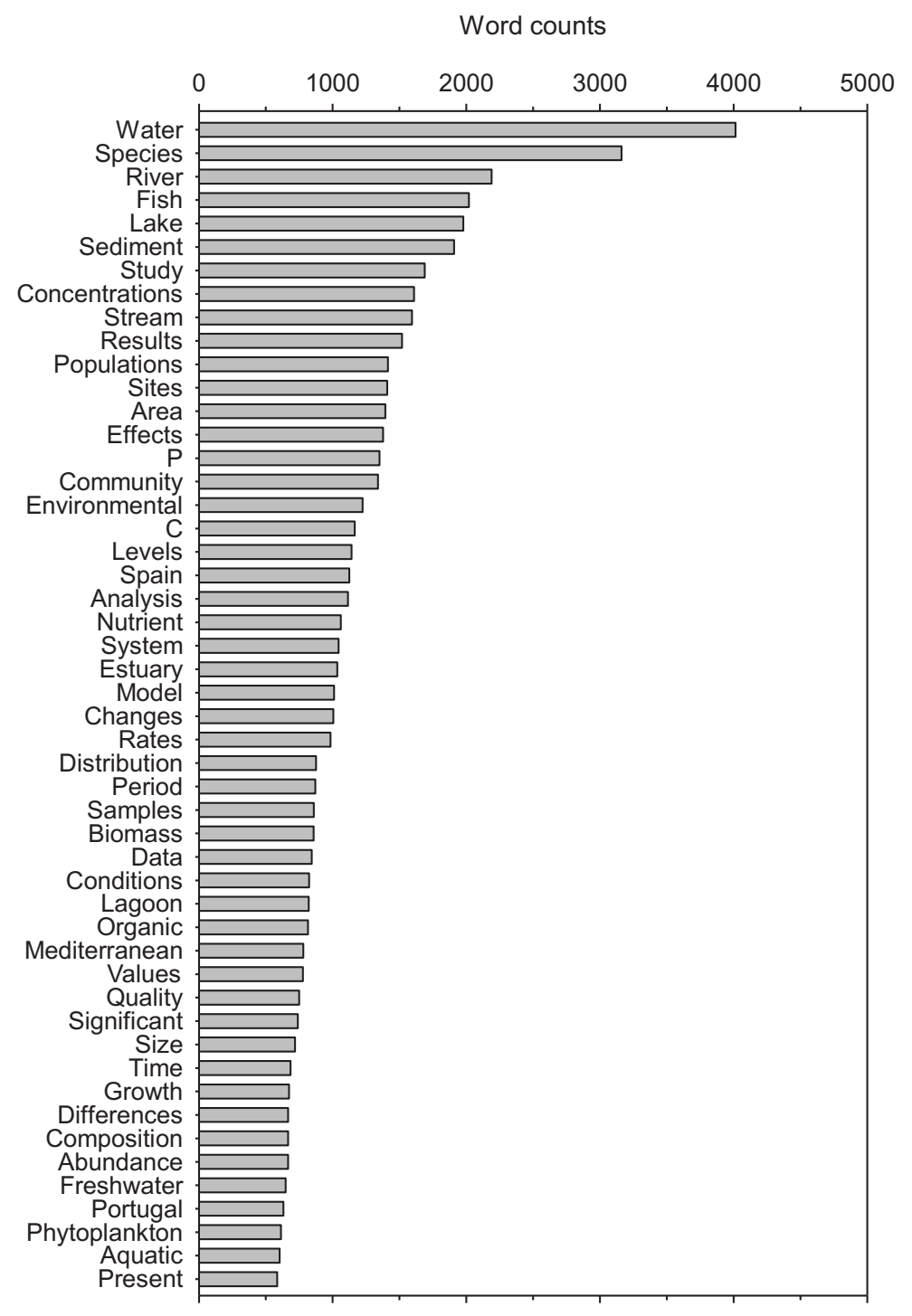

Figure 6. The 50 most frequent terms appearing in the titles and abstracts of the publications of the Iberian limnological research between 2000-2009. General terms such as "study", "results" or "area" were included to avoid bias during subjective selection (e.g., high frequency of appearance of "area" can refer to the "studied area" but also to the existence of papers working on spatial issues). P: phosphorus; C: carbon. Los 50 términos más frecuentes que aparecen en los títulos y resúmenes de las publicaciones en investigación limnológica ibérica durante la década 2000-2009. Se incluyen términos de carácter general como "study", "results" o "area" para evitar sesgos asociados al criterio de selección de términos (por ejemplo, una alta frecuencia de aparición de "area” puede hacer referencia al área de estudio pero también a trabajos sobre aspectos espaciales). P: fósforo; C: carbono. 
water (366), Riparian (200), Fluvial (121), Floodplain (89), Inland water (56), Swamp (45), Lentic (43), Lotic (30), Impoundment (18), Hyporheic (17), and Endorheic (10). On the other hand, the terms depicting the biological character of Iberian limnological research were amongst the most frequent (species, population, and community, ranked $2^{\text {nd }}, 11^{\text {th }}$ and $16^{\text {th }}$, respectively). This agrees well with the eminent fluvial character of Iberian limnological research and with the dominance of biological limnology over more chemical subdisciplines, as described above. However, some terms referring to chemical limnology also appeared in relatively high positions, such as concentration, $P$ (for phosphorus) and $C$ (for carbon), which ranked $8^{\text {th }}, 15^{\text {th }}$ and $18^{\text {th }}$, respectively. The first terms related to any group of organisms were fish (ranked $4^{\text {th }}$ ) and phytoplankton (ranked $48^{\text {th }}$ ), which suggests a strong focus of Iberian researchers on these groups over other groups such as zooplankton (ranked $172^{\text {nd }}$ ) and bacteria (ranked $186^{\text {th }}$ ). Surprisingly, despite the frequent use of macroinvertebrates in biomonitoring in the Iberian Peninsula, these organisms appeared in a very low position (ranked $228^{\text {th }}$ ), indicating again that a large portion of this research has been disseminated through other types of publications, likely to ensure its transfer to water managers. Finally, the tradition of few limnological studies focusing on amphibians in the Iberian Peninsula is reflected by this group's low rank (1795 ${ }^{\text {th }}$, not shown).

\section{CONCLUSIONS}

Limnological research performed in the Iberian Peninsula during the decade 2000-2009 covered all disciplines, scientific focuses, and environments, despite having a marked local focus on fluvial systems covering a small geographical range within the Iberian Peninsula. The research was primarily biological and addressed fundamental rather than applied or methodological questions regarding inland waters; it was vastly dominated by observational approaches, only occasionally relying on experimental designs. The quantitative bibliometric analysis performed here indicates that Iberian research on limnology was in good health just before the current cuts to public investment in science. Given the current economic situation, the future of Iberian limnological research is uncertain. Public investments have been significantly reduced in Spain and Portugal, and Iberian researchers are now even more dependent on international grants in cooperation with other researchers. Despite this could potentially spur an increase in the scale of research (a research gap identified herein), there are many topics identified in our analyses that will require local-scale studies and thus will urge public investments by local or state administrations. This is especially important in the Iberian Peninsula where many unique limnological environments exist, such as temporary, salt, and karstic water bodies, which require attention given current global pressures.

\section{ACKNOWLEDGEMENTS}

We would like to thank our colleagues from the Iberian Association of Limnology, in particular Joan Armengol, for inspiring us and encouraging us to perform this study. We also thank Narcís Part and Núria Catalán for valuable comments on an earlier version of the manuscript. BO acknowledges the CARBONET project (CGL2011-30474-C02-0) funded by the Spanish Ministry of Science and Innovation. NB acknowledges the RICHABUN project funded by the Spanish Ministry of Education and Science FEDER (CGL2007-60163/BOS).

\section{REFERENCES}

ÁLVAREZ-COBELAS, M. A., C. ROJO \& D. G. ANGELER. 2005. Mediterranean limnology?: current status, gaps and the future of Mediterranean freshwater ecosystems. Journal of Limnology, 64: 1329.

ANTHONY, L. 2013. AntWordProfiler (Version 1.4. 0.1) [Computer Software]. Tokyo, Japan: Waseda University. Available from http://www.antlab.sci. waseda.ac.jp/ 
CHINCHILLA-RODRÍGUEZ, Z., E. CORERA-ÁLVAREZ, F. MOYA-ANEGÓN \& L. SANZ-MENÉNDEZ. 2010. Indicadores bibliométricos de España en el Mundo 2008. Instituto de Políticas y Bienes Públicos (IPP), CCHS-CSIC. Documento de trabajo, Numero 13. http://hdl.handle. net/10261/27465

COLE, J. 2009. Limnology as a discipline. In. Encyclopedia of Inland Waters. G. E. Likens (ed.): 613. Oxford: Elsevier.

KALFF, J. 1991. On the teaching of limnology. Limnology and Oceanography, 36: 1499-1501.

LEWIS, W. 1995. Limnology as seen by Limnologists. Journal of Contemporary Water Research and Education, 98: 4-8.

LUUKKONEN, T. 1990. Invited review article: bibliometrics and evaluation of research performance. Annals of Medicine, 22: 145-150.

MANE, K. \& K. BÖRNER. 2004. Mapping topics and topic bursts in PNAS. Proceedings of the $\mathrm{Na}$ tional Academy of Sciences, 101: 5287-5290.

MORO-MARTÍN, A. 2012. Spanish changes are scientific suicide. Nature, 482: 277.
MOYA-ANEGÓN, F. (dir); CHINCHILLA-RODRÍGUEZ, Z (coord.). 2007. Indicadores bibliométricos de la actividad científica española (19902004). Fundación Española para la Ciencia y la Tecnología. Madrid

NATURE EDITORIAL. No turning back. Nature, 462: 137-138.

NORTHCOTE, T. \& J. LOBÓN-CERVIÁ. 2008. Increasing experimental approaches in stream trout research -1987-2006. Ecology of Freshwater Fish, 17: 349-361.

RUSSELL, J. \& R. ROUSSEAU. 2002. Bibliometrics and institutional evaluation. In: The Encyclopedia of Life Support Systems (EOLSS). K. Rosner (ed.): 42-64. Developed under the Auspices of the UNESCO, Eolss Publishers, Oxford, UK, http://www.eolss.net

SANZ, L \& L. CRUZ. 2010. Análisis sobre ciencia e innovación en España. Fundación Española para la Ciencia y la Tecnología (FECYT), Madrid, 850 pp.

THOMSON REUTERS 2009. Journal Citation Reports $囚$ Science Edition. 